$\frac{12}{3-1}-9585(1)$

UCRL-ID-118720

\title{
Benchmarking of Multiple Preequilibrium Routines in GNASH
}

\author{
M. B. Chadwick \\ P. G. Young
}

August 1994

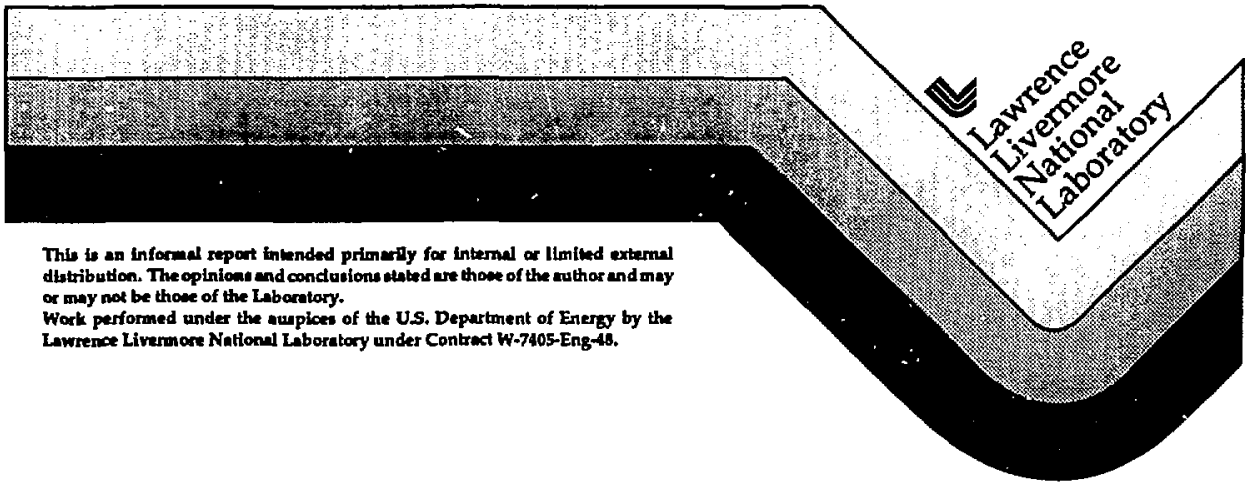




\section{DISCLAIMER}

This document was prepared as an account of work sponsored by an agency of the United States Govemment. Nelther the United States Government nor the University of California nor any of their employees, makes any warranty, express or implied, or assumes any legat liability or responsibllity for the sccuracy, completeness, or usefulness of any information, apparatus, product, or process disclosed, or represents thut iv wee would not infringe privately own rights. Reference herein to any spedific commercial products, process, or ! rice by trade name, trademark, manufacturer, or otherwise, does not necesearily contitute or imply lts endorement, recomenendation, or favoring by the United States Government or the University of Caliform. The views and opinions of authors expresed herein do not neceasarily state or reflect those of the United State Covernment or the Univeraity of Callfornin, and shall not be used for adverticing or product endormenent purposes.

This report hus been reproduced directly from the best available copy.

Available to DOE and DOE contractors from the Office of Sclentific and Technical Information P.O. Box 62, Ouk Ridge, TN 37331

Prices available from (615) 576-8401, FTS 626-8401

A vailable to the public from the National Techrical Information Service

US. Deputurent of Counure 5285 Port Royal Rd. Springfleld, VA 22161 


\title{
Benchmarking of multiple preequilibrium routines in GNASH
}

\author{
Ai.B. Chadwick ${ }^{(1)}$ and P.Ci. Young ${ }^{(2)}$ \\ (1) Iniversity of California, Lawrence Livermore National Labaratory. \\ Nuclear Division, Livermore, California 94551 \\ (2) University of California, Los Alamos National Labaratory. \\ Theory Division, Los Alamos, NM87545
}

\begin{abstract}
We comparr two different. models for multiple preequilibrium enission (MPE) in (iNASH: the olker exciton MPE model ; and a new "generalized MPE" model which is parameter-free. Wc analyze the proton-induced reactions on zirconium and leact. which were the focus of a recent NEA intermediate-energy code intercomparison, using both the MPE nodels. We find that the new generalized MPE model better describes the measurements.
\end{abstract}

Multiple prcequilibrium enission (MPL) refers to processes in which more than one fast preequilibrium particle can be emitted in a nuclear reaction. Once the in. cident energy in nucl un-induced reactions exceeds about $50 \mathrm{MeV}, \mathrm{MPE}$ become. increasingly important. When comparing calculations with experimental datia there are two types of phenomena which are impacted by MPE processes: (1) nucleon emission spectra (specifically, accounting for the high-energy differential spectra while i mult ancously maintaining flux conservation); and (2) describing ('xcitation functions, "bere the propulation of a particular residual nucleus is dramatically iullueteced by the MPE nodeling.

The unclear modeling code GNASH was modified to inclind MPE prucesus in 1991. using an exciton model description [1]. This version of GNASIl wats used to analyze the LAMPF/WNR (n, xny) measurements of excilation functions. ard MPE was shown to be very important [2]. In addition, this version was also used to calculate $(p, x n)$ and $(p, x p)$ reactions on ${ }^{90} \mathrm{Zr}$ and ${ }^{20 x} \mathrm{~Pb}$ for the VEA intermediate. energy code intercomparison [3]. organized by Blann and Vagel. Again, the modeling described the data fairly well when WIPE was included [1]. However, sone weaknesses in the exciton MPE modeling were noticed - the MPE emission spertra in sonk cases appeared too hard, overpredicting the highest energies. and underpredicting the lower emission energies. This follows fron the simplifying assumption about the doninance of $1 p 1 h$ in MPE, made in the exciton model MPE algorithm [1]. Also, this algorithrn 
requires the input of a parameter describing the preequilibrium damping processes which is not always well known, and in practice it is often treated as a frec parameter with which to optimize the fit to measurements.

Ine to the above-mentioned limitations of the original exciton-model $\mathrm{N1} / \mathrm{l}$, algorithm, we developed a new "generalized MPE" model, which is parameter free. It is "generalized" since it can always be used to determine MPE. whatever preequilibrium model is used for the primary preequilibrium emission (whether exciton model, or FKK). We described this model in detail in Ref. 15]. Since this model accounts for preequilibrium emission from the various $p-h$ configurations, it gives a softer spectrum compared to the original exciton model MPE algorithm, and tends to describe emission spectra more accurately.

In this report we compare thr two MPE model's ability to account for the emission spectra for the reactions studied in the NEA code intercomparisor. 'The figures show the GASAl composite spectrum results for inclusive nucleon enission in the protoninduced reactions on lead and zirconium, compared with experimental data where they exist. We show the tolal spectrum results obtained using both the new and the older MPE models, as well as the MPE contribution from the new model. The old MPE model contributions can be found in our report of the GNASH calculations for the NEA code intercomparison [4]. We have the following general obscrvations:

- For the $160-\mathrm{McV}$ induced reactions, the old MPE model underpredicts the measurements in the 20-50 MeV emission energy region. The new generalized MPL model better describes the measurements here. This same underprediction of the lower emission-energy data also occurs in the $80-\mathrm{MeV}$ intuced reactions, but to a lesser extent.

- At the higher emission energies, in the 80 and $160-\mathrm{MeV}$ induced reactions, there are cascs where the old MPE model results are too high. Again, the new generalized MPl nodel better describes the moasurements.

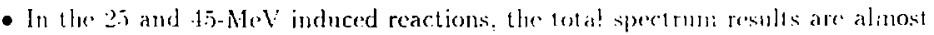
identical when nsing the two MPE models. 31 is becallse in hoth rasen the MPE contributions are small compared to primary presquilibrium entssion.

In sunnary, the new generalized MPE model provides al improvenent to the modeling of emission spectira in higher-energy reactions. The softer spectral shape of the generalized MPli model. compared to that found with the older exciton model routine, agrees better with measurerents. Also. the new generalized MPV thes the advantage of being parameter-free. As a further test. we intend to assess our new generalized MPE model's ability to describe the l.AMPF/WNii $(n, x n \gamma)$ excitation functions. 


\section{REFERENCES}

[1] P.G. Young, E.D. Arthur, and M.B. Chadwick, Comprehensive Nuclear Model Calculations: Introduction to the Theory and Lise of the GNASH Code. Los Alarros National Laboratory Document LA-12343-MS (1992).

[2] H. Vonach, A. Pavlik, M.B. Chadwick, R.C. Haight, P.O. Nelson, S.A. Wender, and P.G. Young, ${ }^{207.208} \mathrm{~Pb}(n, x n \gamma)$ reactions for neutron energies from 3 to 200 MeV. submitted to Physical Review C, (1994).

[3] M. Blann, H. Gruppelarr. P. Nagel, and J. Rodens, International Code Comparison for Intermediate Energy Nuclear Dala, Nuclear Energy Agency, OECD. (1991).

[4] P.G. Young and M.B. Chadwick, Calrulation of Prolon and Veutron Fistion Spectra From Proton Reactions With ${ }^{90} \mathrm{Zr}$ and ${ }^{208} \mathrm{~Pb}$ to $160 \mathrm{Mr}$ with the GNASII Code. in the Procecdings of the Specialist Mecting on Intermedrate Energy Nuclear Data, Issy-les-Moulineaux, Paris, France, 30 May - I June, 1994, edited by P. Nagel (OECD, Paris, 1994), in print.

[5] M.B. Chadwick, P.G. Young, D.C. George, Y. Watanabe, Mnltiple Preequilibrium Emssion in Foshonch-Lerman-Loonin Analyses, Physical Review C. in print. $(19)+4)$.

\section{DISCLAIMER}

This report was prepared as an account of work sponsored by an agency of the United States Government. Neither the United States Governmenl nor any agency thereof, nor any of their employees. makes any warranty, express or implied, or assumes any legal liability or responsibility for the accuracy, completeness, or usefulness of any information, apparatus. product, or brocess disclosed, or represents that its use would not infringe privately owned rights. Reference herein to any specific commercial product, process, or service by trade name. Irademark. manufacturer, or otherwise does not necessarily constitute or imply its endorsement, recommanter favoring by the United States Government or any agency thereof. The views mendation, of favoring by the United States Gavernment of any do necessarily state or reflect those of the United States Government or any agency thereof. 


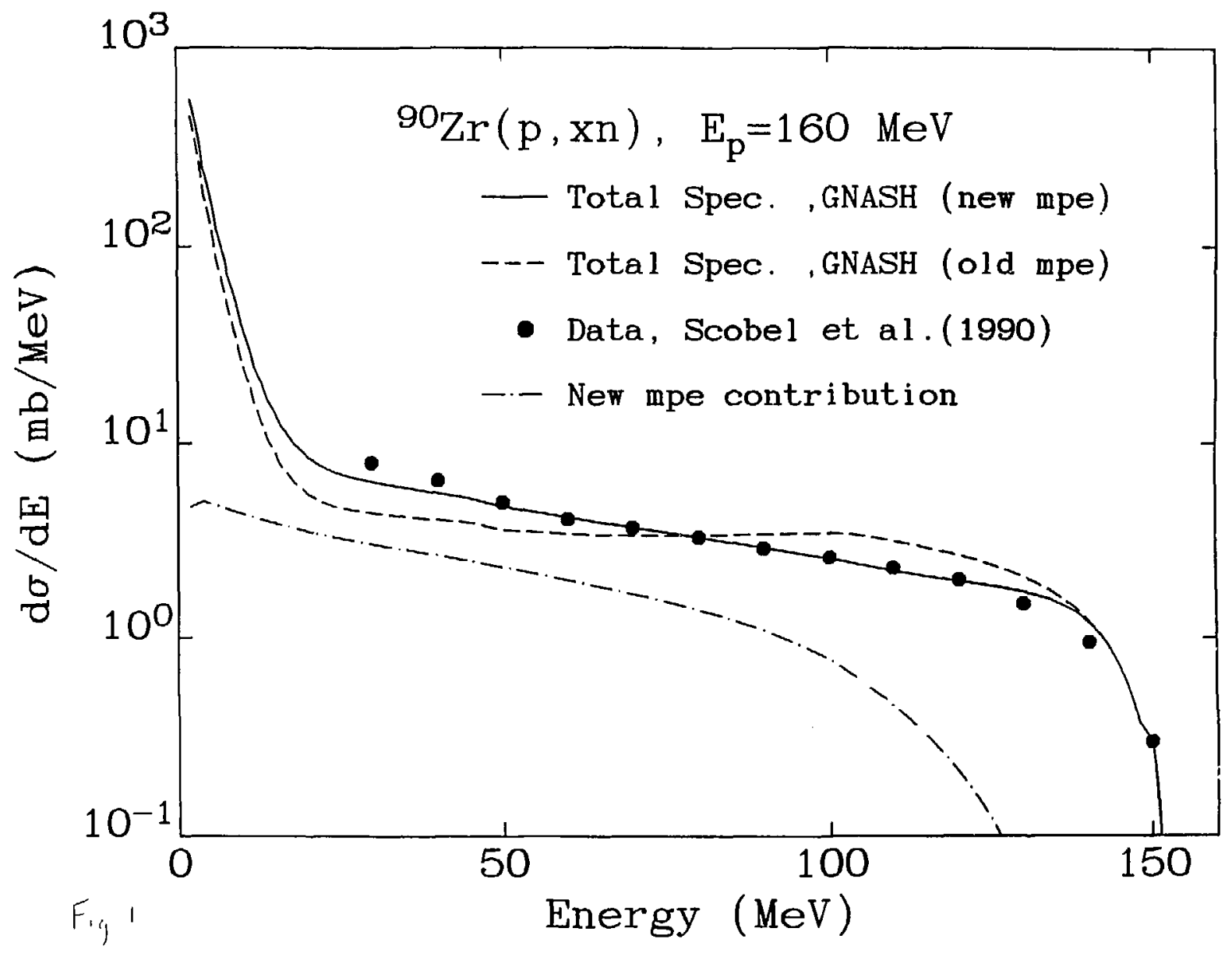




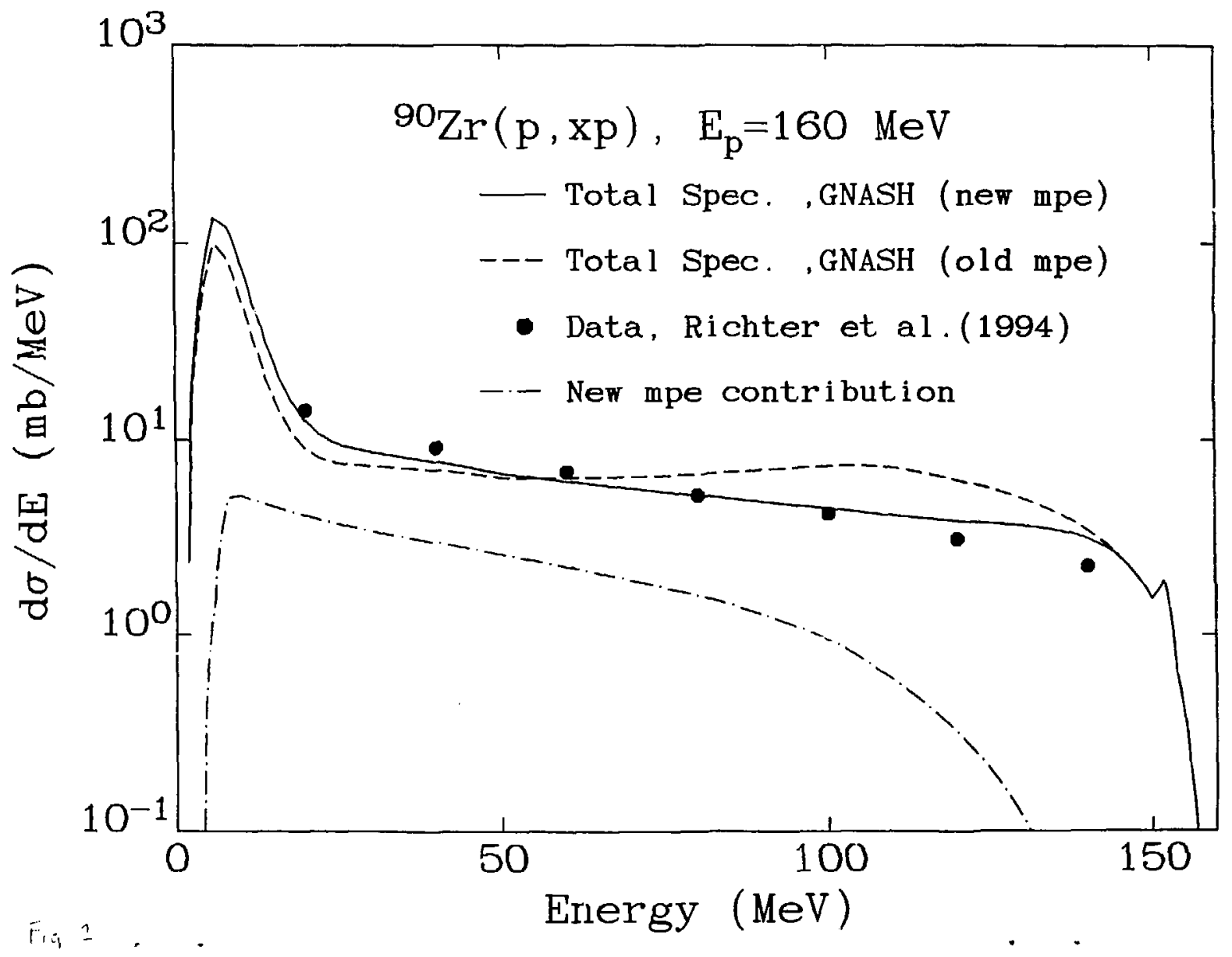




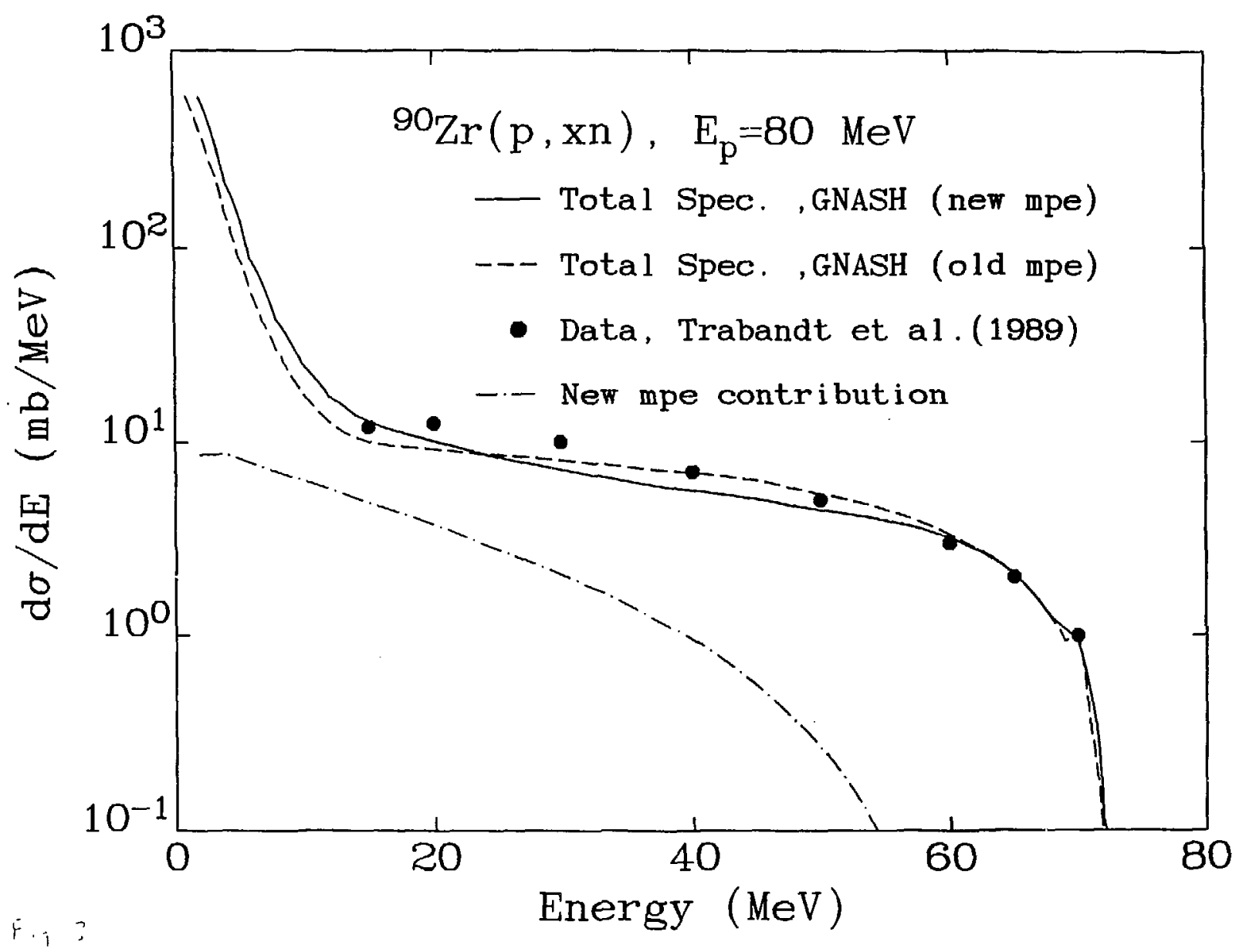




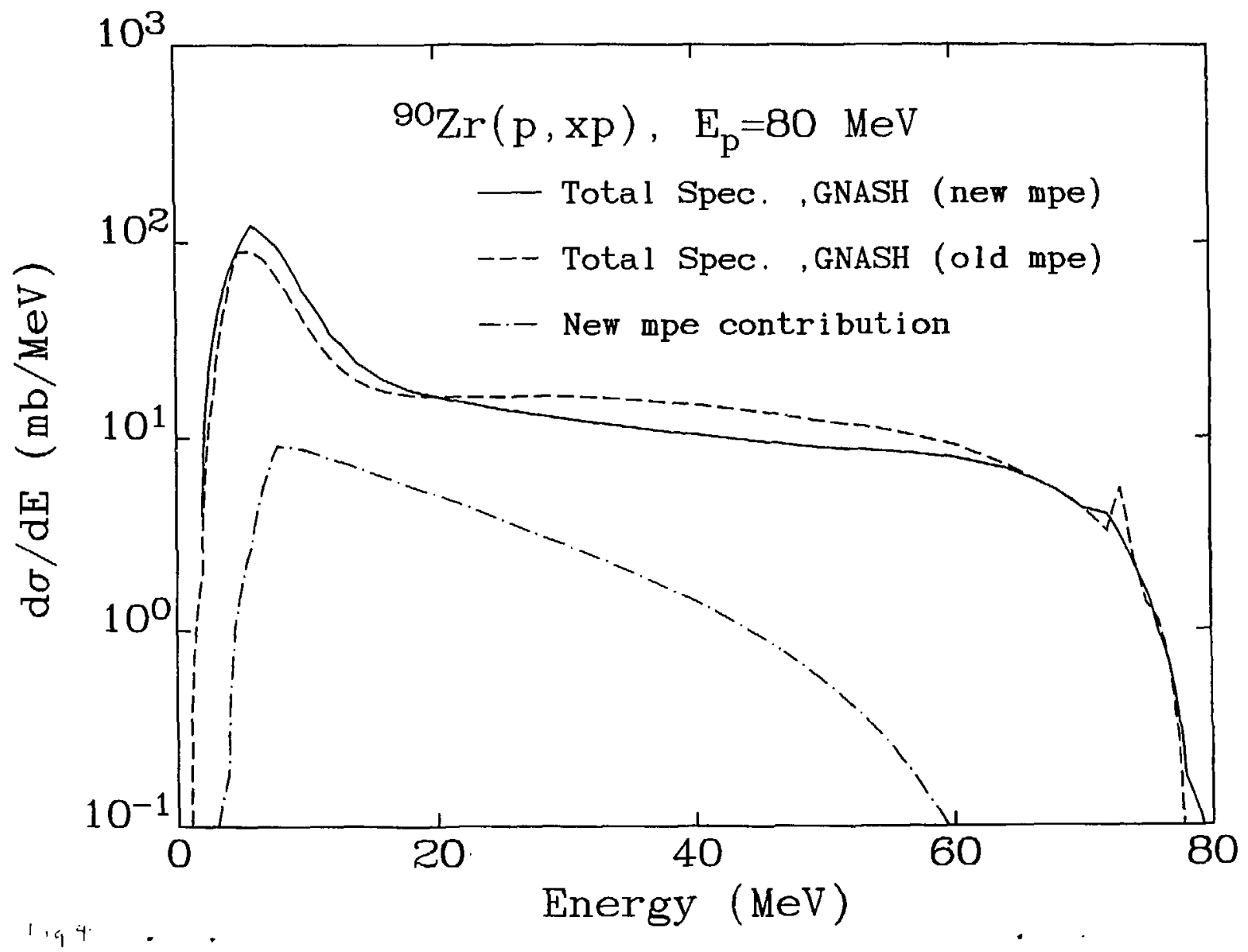




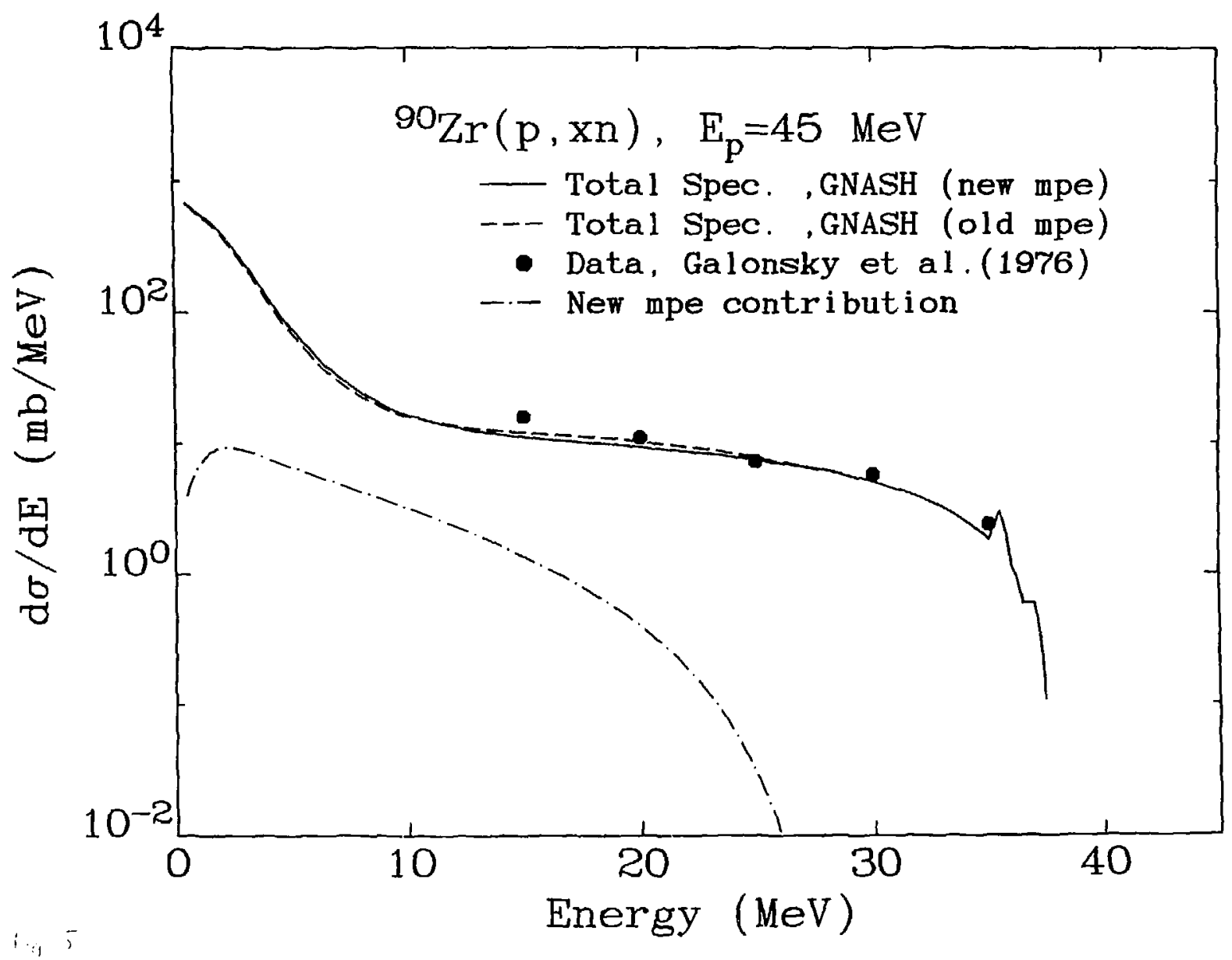




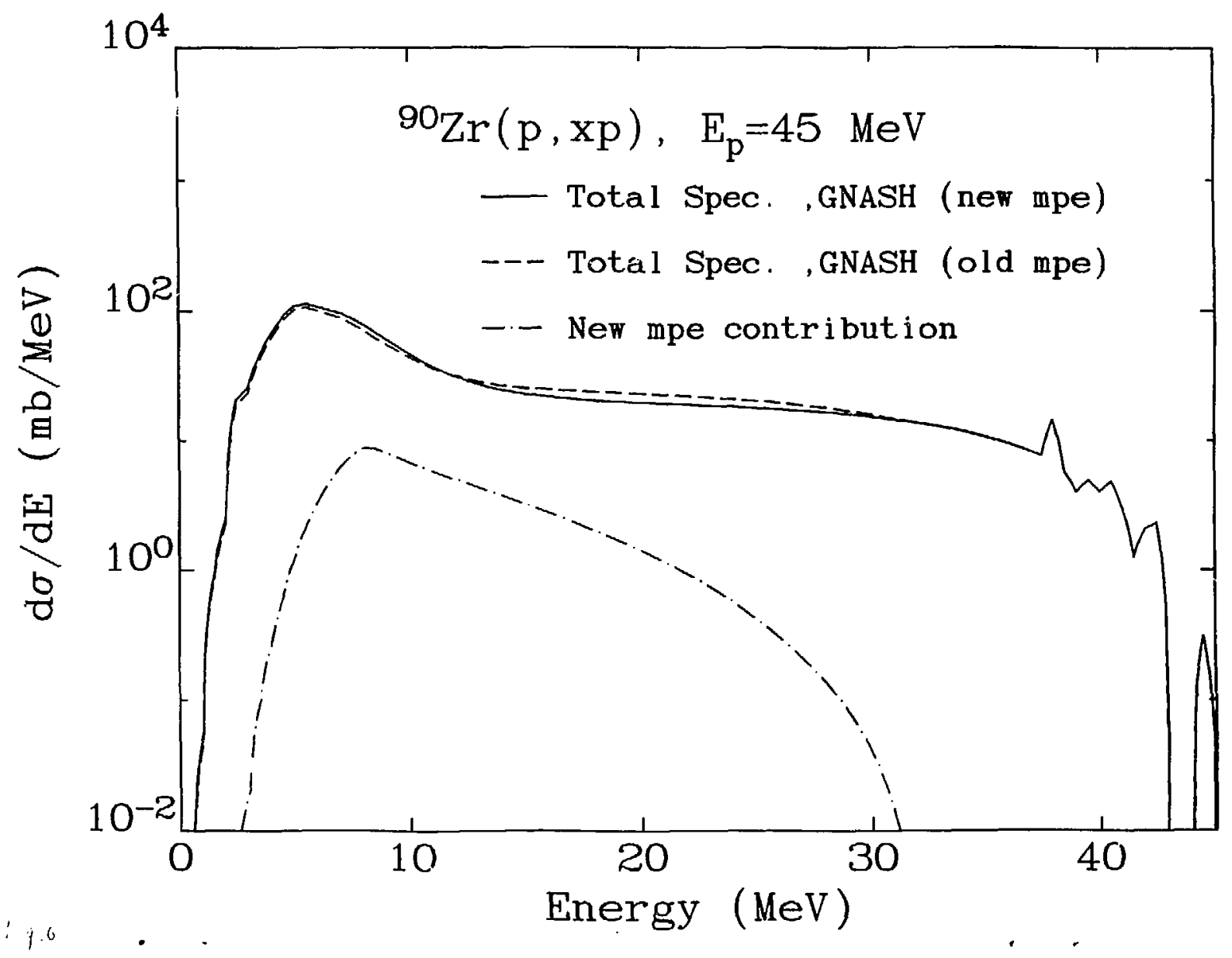




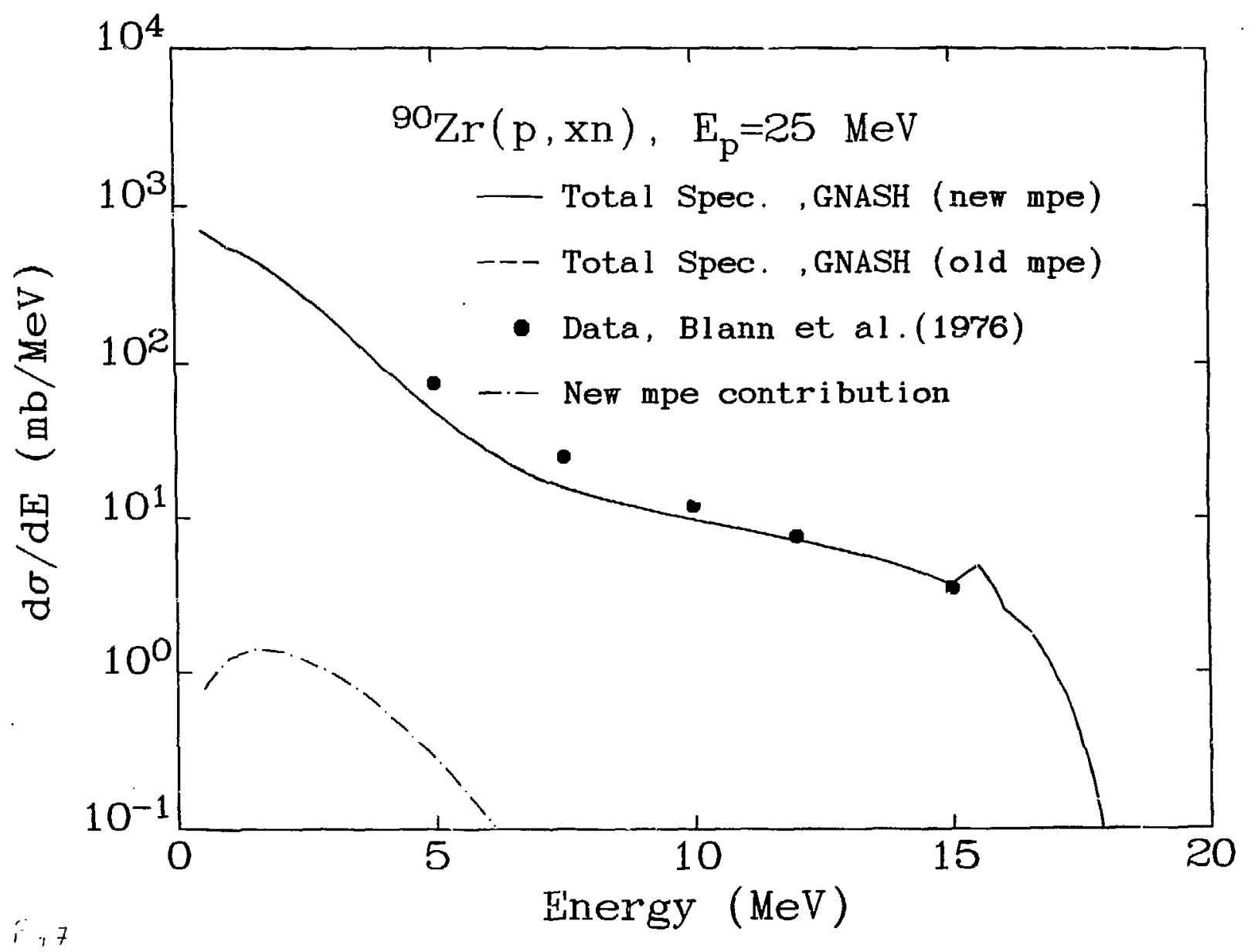




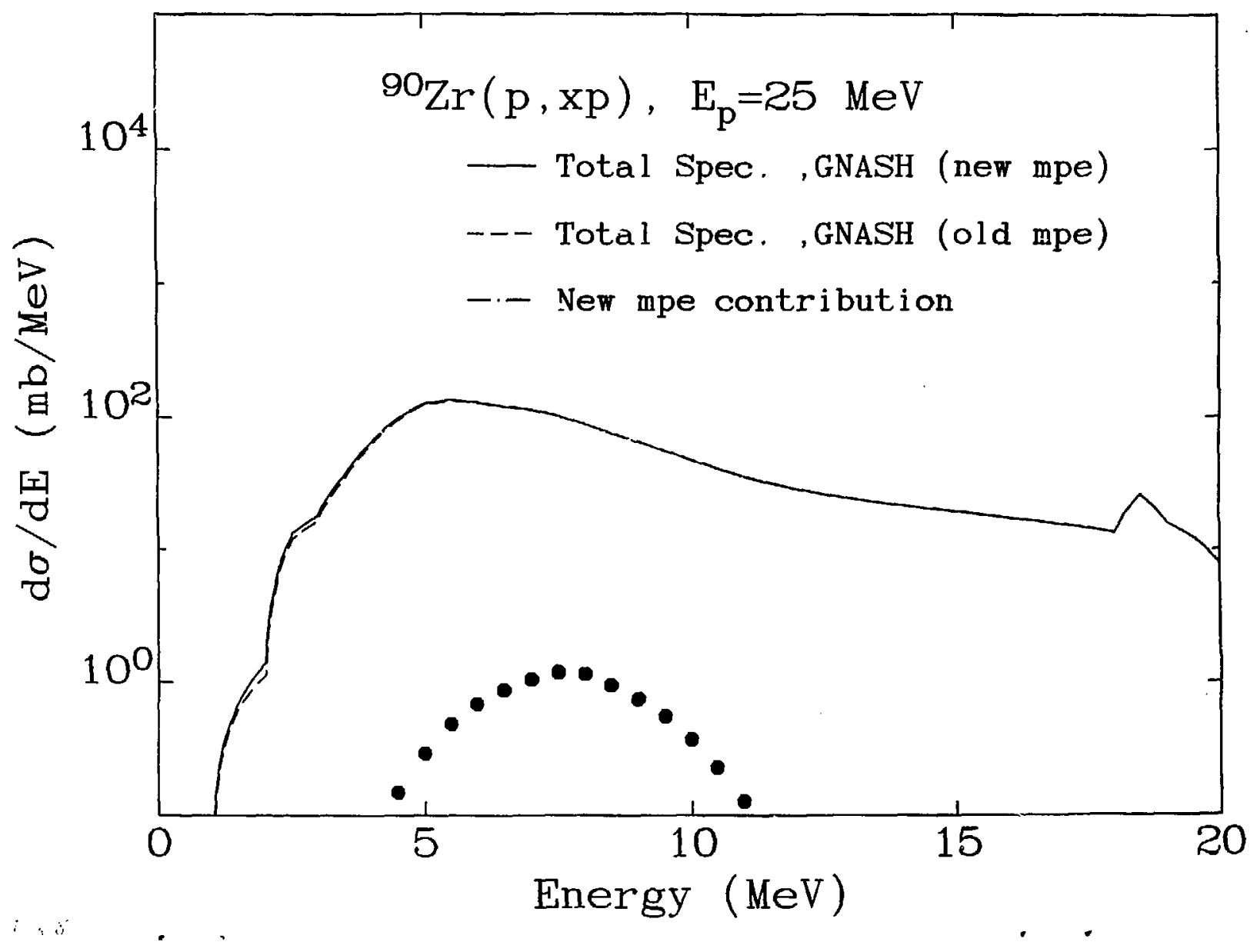




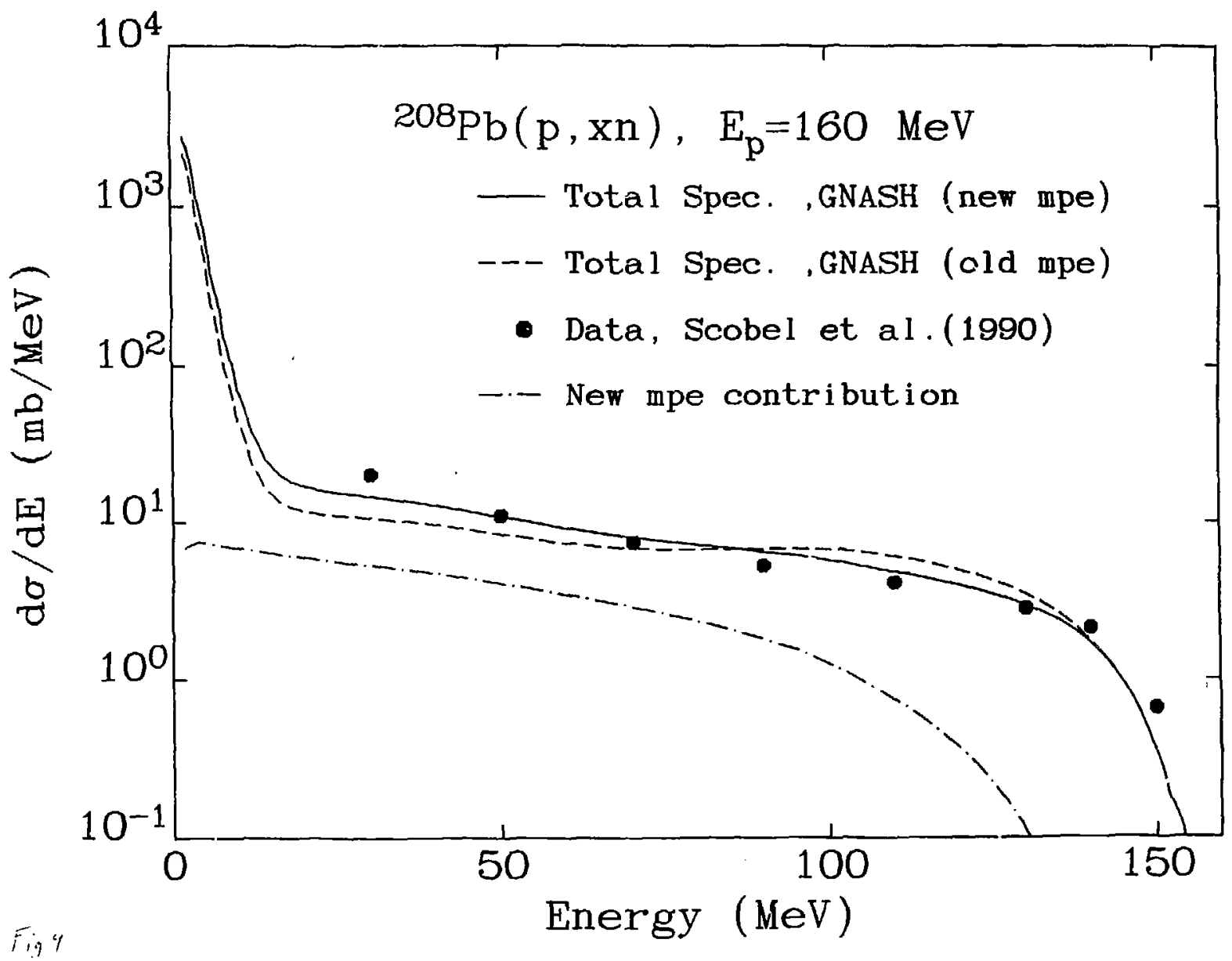




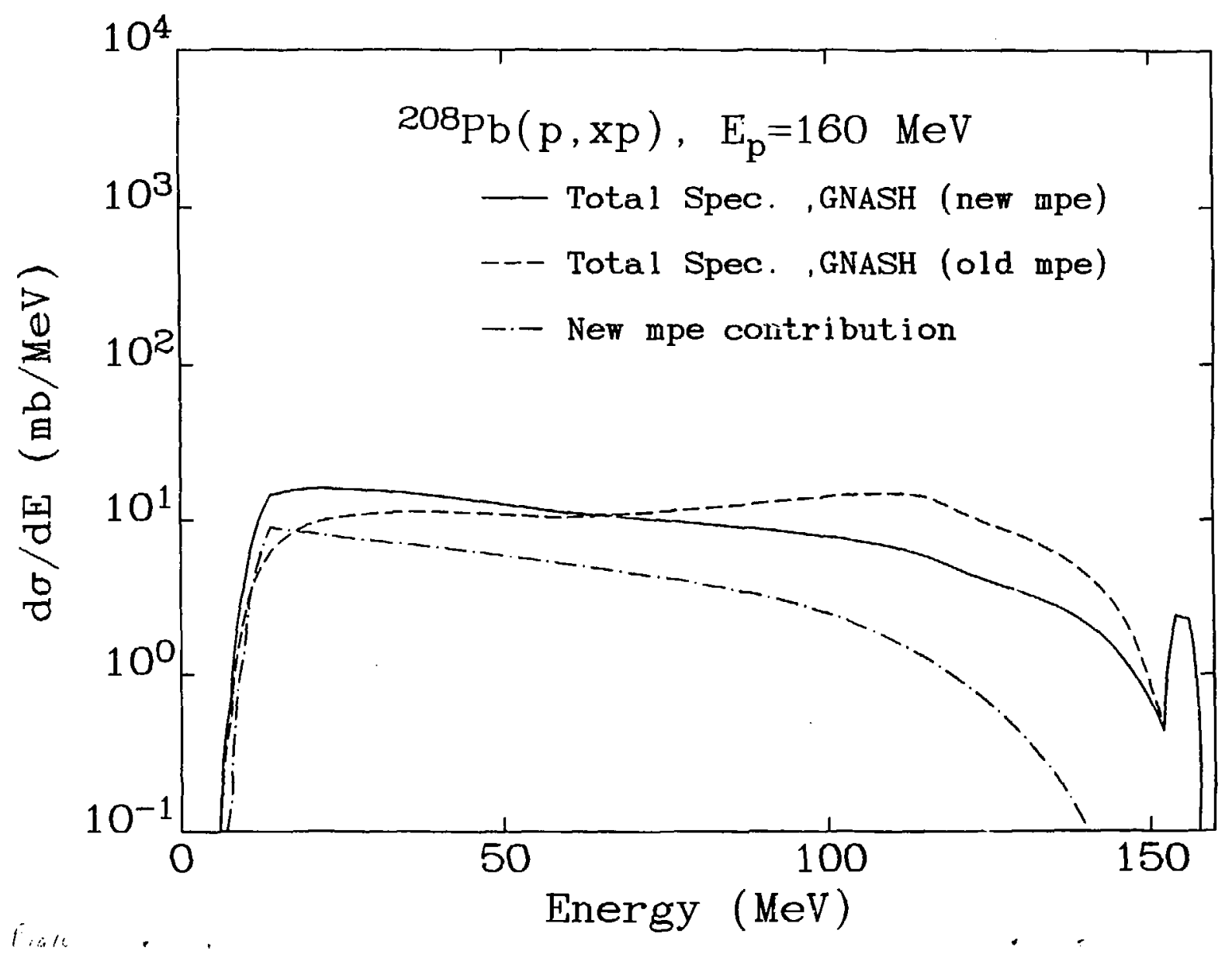




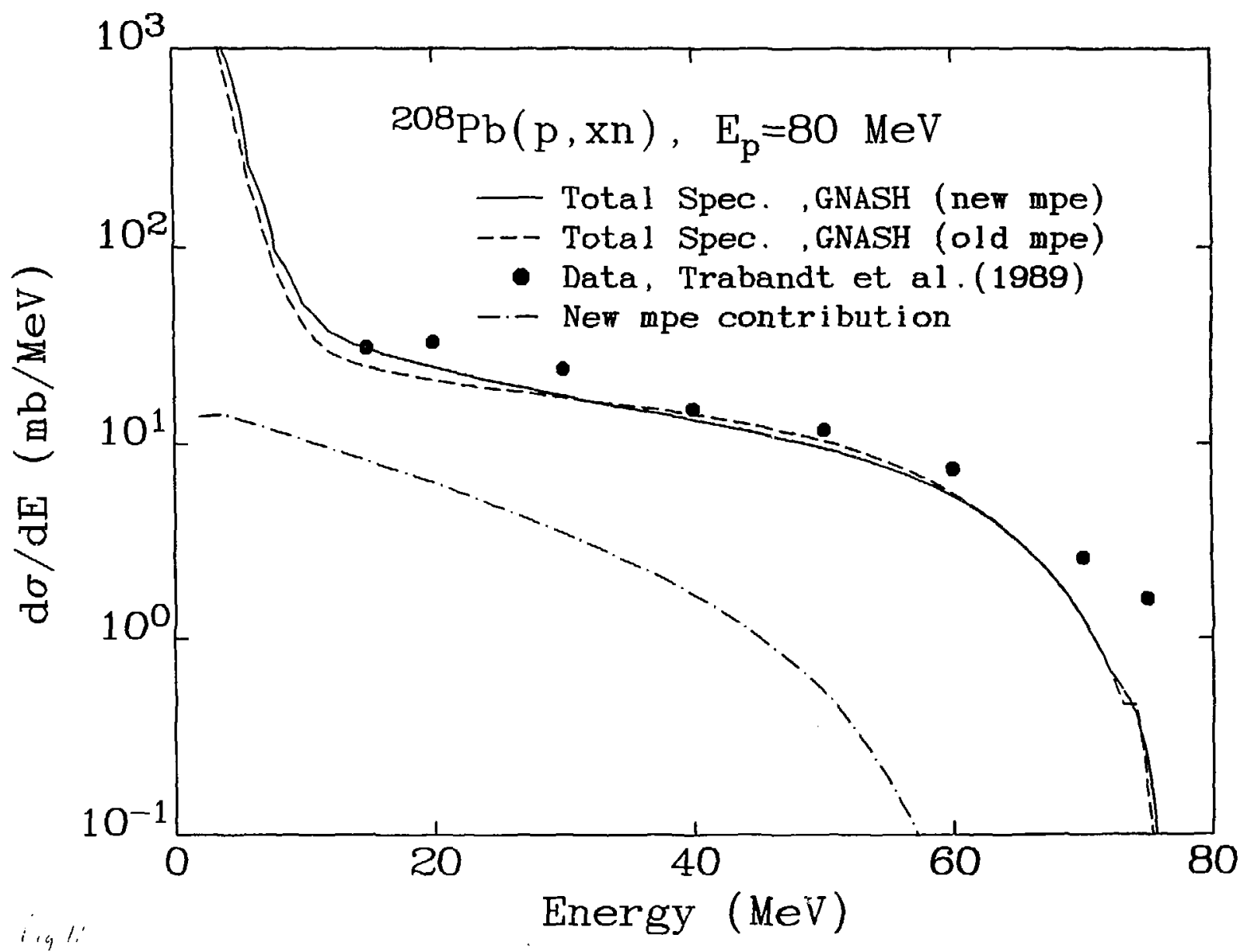




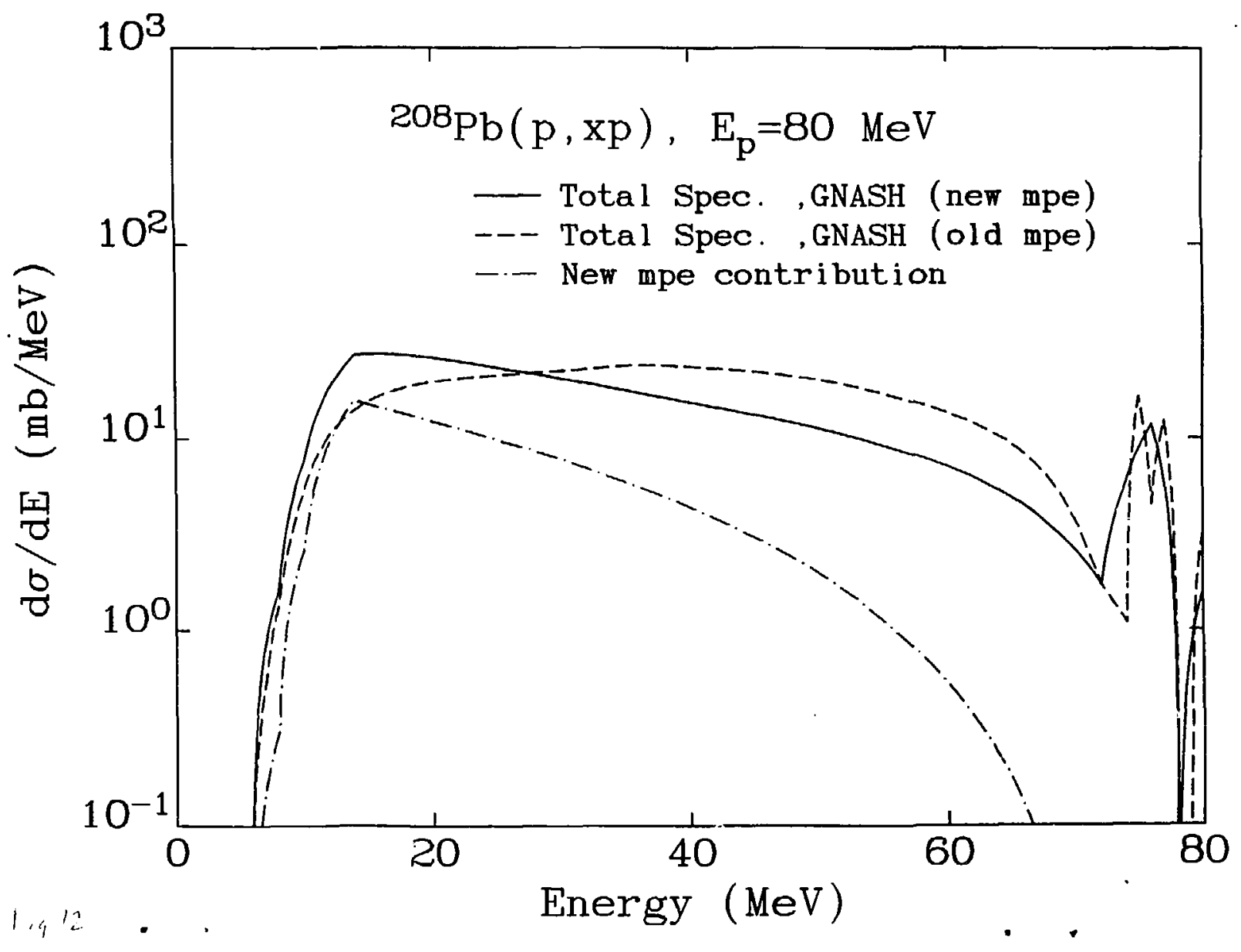

